\title{
A MEDIAÇÃO PEDAGÓGICA EM FÓRUNS DE DISCUSSÃo NOS CURSOS VIRTUAIS
}

\author{
Me. Daiane Grassi ${ }^{1}$ - UFRGS - daianegrassi@gmail.com \\ Esp. Janile Moiano da Silva ${ }^{2}$ - IPA - janilesilva@yahoo.com.br
}

\begin{abstract}
Resumo:
Muito tem se discutido quanto a qualificação dos profissionais que atuam na Educação a Distância (EAD). Um dos recursos mais utilizados na realização de cursos virtuais é a ferramenta de comunicação assíncrona fórum, considerado também como um instrumento efetivo de ensino e aprendizagem. A partir da vivência como profissional da área e como discente, surge a intenção de explorar este recurso na oferta de um curso a distância de Extensão intitulado 'A mediação pedagógica em fóruns de discussão nos cursos virtuais'. O objetivo do curso será promover a formação continuada dos profissionais envolvidos na $\mathrm{EAD}$, no que se refere ao uso do fórum como um recurso de mediação pedagógica. Este curso terá duração de 40 horas e será realizado em um período de 2 meses. Ao longo do curso, os alunos desenvolverão atividades individuais e em grupo, explorando através destas estratégias de utilização da ferramenta de comunicação fórum.
\end{abstract}

Palavras-chave: Educação da Distância. Mediação Pedagógica. Interatividade. Fóruns de Discussão.

\begin{abstract}
:
Much has been discussed about the qualification of the professionals that work with Distance Learning (DL). One of the most used resources on the virtual is the forum tool, wich involves asynchronous communications, also considered as an effective instrument of teaching and learning. Starting with professional experience in the area and as a student, arises the intention in explore this resource in the offer of a Distance Learning Course, named 'The Pedagogic Mediation On Virtual Courses Discussion Forums'. The course objective will be to promote the continued formation of the DL involved professionals, referring to the forums' use as a resource of pedagogic mediation. This course will have a duration of 40 hours and will be realized during 2 months. During the course, the students will develop individual and group activities, exploring through this activities the utilization of the communication tool forum.
\end{abstract}

Keywords: Distance Learning. Pedagogic Mediation. Interactivity. Discussion Forums.

\footnotetext{
${ }^{1}$ Pedagoga Multimeios e Informática Educativa pela PUCRS, Especialista em Informática na Educação pelo CINTED/UFRGS e Mestranda em Educação pela UFRGS.

${ }^{2}$ Bacharel em Psicopedagogia Clínica e Institucional pela PUCRS - 2006/2 - e Especialista em Educação a Distância pelo SENACRS - 2009/2.
} 


\section{Introdução}

Muito tem se discutido sobre a qualidade na oferta e na realização de cursos em EAD, bem como nas relações (comunicação, interação e interatividade) estabelecidas para este fim. Esta idéia perpassa pelos novos papéis exigidos pela sociedade, em que professores sejam capazes de assumir posturas desafiadoras frente às informações abordadas no curso e que provoquem e instiguem nos alunos a postura autônoma e de autoria de seus conhecimentos.

Seguindo este pressuposto, busca-se o conceito de aprendizagem colaborativa em Ambientes Virtuais de Aprendizagem (AVA), em que os processos de ensino e de aprendizagem estão apoiados na promoção de um espaço de cooperação e colaboração. Mas este tipo de aprendizagem não pode ser somente sugerida/indicada. Ela precisa de um profissional/educador que acompanhe, anime, desafie e provoque. Em outras palavras, que seja capaz de mediar diferentes situações durante este processo, instigar e fazer refletir nos aprendizes quais os significados do processo de aprendizagem de cada um, das informações que estão sendo abordadas. Não somente sugerir uma discussão e "largar nas mãos dos alunos", por exemplo, na introdução de um Fórum de Discussão, principalmente em inícios de curso a distância, em que muitos alunos não estão habituados com esta modalidade de ensino e de aprendizagem. De acordo com Morgado (2001), este aluno precisa de um profissional que o acompanhe mais inicialmente e aos poucos o vá liberando e favorecendo o desenvolvimento das suas competências e autonomia de aprendizagem, de se sentir autor das suas ações.

Dessa forma, o projeto de oferta do curso 'A mediação pedagógica em fóruns de discussão em cursos virtuais', está voltado para profissionais de diferentes áreas que estejam interessados em aprofundar seus estudos sobre a utilização metodológica da ferramenta de comunicação Fórum na modalidade EAD. Seu objetivo geral leva em destaque: promover a formação continuada dos profissionais envolvidos na EAD, no que se refere ao uso do fórum como um recurso de mediação pedagógica.

$\mathrm{O}$ interesse em abordar esta temática, partiu de nossas experiências profissionais, como educadoras, bem como pela vivência como alunas virtuais.

Durante os cursos realizados, percebeu-se com frequiência o questionamento de estudantes quanto a exigência da participação em fóruns de discussão, o que acabava por induzir somente a sua participação e não a interação entre os diferentes membros do grupo. Em outros momentos, a fuga do tema era clara e não havia um educador presente para conduzir/mediar esta discussão. Já em outros, não havia orientações prévias quanto a utilização da ferramenta e a dinâmica utilizada (criando novos tópicos ou respondendo ou acrescentando mensagens em locais que não correspondiam a proposta), e isso acabava por desmotivar o grupo. Também havia momentos em que o grande fluxo e as trocas de informações tornaram-se extensas, proporcionando uma leitura cansativa, desestimulando a participação do aluno em seu posicionamento frente ao tema em discussão.

Além destas vivências, estudos e publicações de $\operatorname{artigos}^{3}$ recentes abordam a necessidade de aprofundamento na utilização dessa ferramenta, levando em conta os

\footnotetext{
${ }^{3}$ BARRETO, Luis Augusto Nery. O fórum como instrumento de aprendizagem em educação a distância. v. 1, n.2, Art.6. E-Revista Facitec, dezembro de 2007. Disponível em: http://www.facitec.br/seer/ojs/viewarticle.php?id=53\&layout=html. Acesso em: jul. de 2009. JACOBSOHN, Liliane Vasconcellos; FLEURY, Maria Tereza Leme. A contribuição do fórum de discussão para o aprendizado do aluno: uma experiência com estudantes de administração. Caderno de Pesquisas em Administração, São Paulo, v. 12, n. 1, p. 69-80, janeiro/março 2005. Disponível em: http://www.ead.fea.usp.br/cad-pesq/arquivos/v12n1art6.pdf . Acesso em: jul. de 2009.
}

V. $8 \mathrm{~N}^{\mathrm{o}} 1$, EAD, 2010 
processos de comunicação neste espaço, discussões e debates e qualidade dos processos de ensino no meio virtual. Situações como estas apontam a necessidade de estudo e de promoção da formação de profissionais da área na utilização da ferramenta de comunicação fórum em cursos virtuais.

\section{Fundamentação Teórica}

\subsection{A mediação pedagógica: novos papéis em EAD}

Estamos passando por mudanças em que o conhecimento não está somente localizado em uma única pessoa, em um livro, em uma biblioteca, em uma instituição..., de modo que a figura do aprendente ${ }^{4}$ esta passiva à figura do ensinante. Deste paradigma, o qual ainda não está bem definido os seus padrões, sai de cena a postura linear como forma de ensinar e aprender, pela promoção de espaços abertos, contínuos, em fluxo e com trocas entre estes personagens (LÉVY, 2003). Está sendo a oportunidade de fazermos parte das informações, compartilhado e significativo pela coletividade humana.

Neste aspecto, estamos tratando de mudanças qualitativas diante dos processos de aprendizagem dos sujeitos envolvidos, de uma aprendizagem cooperativa, de uma inteligência coletiva. Trazendo um pouco desse modelo desejado, Lévy (1999, p.171) destaca que,

[...] os professores e os estudantes partilham os recursos materiais e informacionais de que dispõem. Os professores aprendem ao mesmo tempo que os estudantes e atualizam continuamente tanto seus saberes 'disciplinares' como suas competências pedagógicas.

Ainda, Lévy (1999) destaca que a evolução do sistema de formação não pode ser dissociada da evolução do sistema de reconhecimento dos saberes, que acompanha e o conduz. Assim, devemos acompanhar as mudanças que ocorrem para compreender a atuação pedagógica. Isso porque os sujeitos conhecem e agem conforme os paradigmas instaurados, inscritos na cultura, no qual estes perpassam pelas relações estabelecidas, que determinam conceitos e comandam discursos e/ou teorias.

Quanto a postura a ser adotada e refletida pela figura do educador, referente a este paradigma, Lévy (1999) destaca que sua competência deve deslocar-se no sentido de incentivar a aprendizagem e o pensamento. Neste contexto, alguns autores destacam diferentes papéis assumidos pelos educadores na sua atuação em AVA.

Palloff e Pratt (2002) destacam o papel do animador, o mobilizador de interações; e do facilitador, oferecendo apoio e direcionando a reflexão. Para Silva (2000), o educador em espaços interativos, será muito mais que um facilitador ou um conselheiro, mas um provocador e desafiador através da comunicação estabelecida.

Já Ramal (2002), relaciona este educador como um dinamizador da inteligência coletiva, o arquiteto cognitivo. Este estará mobilizando o grupo para

PINHEIRO, Ana; MEDEIROS, Paula. A utilização de Fóruns de discussão em contextos de aprendizagem: uma abordagem as relações entre intervenientes. Disponível em http://repositorio.esepf.pt/bitstream/handle/10000/93/Cad_2ForunsDiscusao.pdf?sequence=1, Acesso em: mai. de 2009.

RAMOS, Bruna Sola da Silva. Interações mediadas pela tecnologia digital: a experiência do fórum virtual em um projeto de educação a distância. Disponível em: http://www.abed.org.br/congresso2005/por/pdf/120tca3.pdf. Acesso em: mai. de 2009.

4 “[...] o sujeito aprendente como aquela articulação que vai armando o sujeito cognoscente e o sujeito desejante sobre o organismo herdado, construindo um corpo sempre em intersecção com outro (conhecimento-cultura...) e com outros (pais, professores, meios de comunicação)" (FERNANDEZ, 2001, p. 55). 
produções coletivas, fazendo com que os interesses em comum do grupo norteiem as relações e interações entre a comunidade virtual.

Levando em conta todos estes aspectos citados por diferentes autores, a característica comum entre estes é a MEDIAÇÃO. Mas o que se entende e espera por uma mediação pedagógica?

Belloni (2001, p. 64), destaca que "mediatizar significa conceber metodologias e estratégias de utilização de materiais de ensino/aprendizagem que potencializem ao máximo as possibilidades de aprendizagem autônoma". Quando falamos em EAD, não estamos somente citando um modelo de ensino e de aprendizagem mediado pelas tecnologias, mas um espaço que estará sendo mediado por sujeitos ativos.

O conceito de mediação não deve ser separado das concepções metodológicas e epistemológicas de educação e de mundo do educador. Da mesma forma, cada mediação será singular, ímpar, não sendo possível estabelecer padrões de ações (determinista ou estruturalista) e atitudes (norma geral de conduta) a serem adotadas, ou simplesmente ditas como certas e/ou erradas.

Dessa forma, não será somente apresentar o conteúdo para que os mesmos sejam assimilados e continuamente repetidos, ou apresentar caminhos mais fáceis, estabelecendo rotas fixas a serem seguidas. Prever determinadas situações ou até mesmo fazer com que situações de 'conflito' sejam postas como meio/recurso de mediação irá depender das concepções metodológicas de cada educador, ou seja, entender este mediador numa rede de infinitos tipos de relações. Este educador deverá estar presente diante do processo de ensino e de aprendizagem dos alunos, de forma a mediar estas relações e a desafiá-los, na intenção de incentivar as trocas de informações entre os sujeitos envolvidos neste processo, e também provocando entre eles a busca pelo conhecimento.

\subsection{Interação e Interatividade em EAD}

A introdução da EAD e das novas tecnologias na educação como um todo, vem modificando os conceitos de comunicação estabelecida entre os sujeitos envolvidos neste processo. Como bem destacou Silva (2000), vivemos a transição do modo de comunicação massivo para o interativo. Trata-se aqui do rompimento da lineariedade e a unidirecionalidade entre emissor (figura detentora do saber - representada tradicionalmente pela figura do professor) e receptor (figura passiva frente aos processos, já adaptado a esta metodologia - representada tradicionalmente pelo aluno). Dessa forma, possibilitar a interatividade tornou-se um desafio no meio educacional.

Neste contexto, busca-se a postura de um educador capaz de promover a interação em diferentes espaços educacionais, capaz de favorecer e envolver todos os sujeitos no processo educacional (emissor e receptor) em prol de sujeitos autores, autônomos na construção do conhecimento individual e coletivamente.

Estamos tratando de mudanças nas posturas dos sujeitos envolvidos, na sua postura comunicacional. Quanto a isso, Silva (2003b) destaca que "uma pedagogia baseada nessa disposição à co-autoria, à interatividade, requer a morte do professor narcisisticamente investido do poder". Precisamos de um educador que não esteja preocupado com o controle das ações dos aprendentes, que condiciona/manipula o caminho que o aluno deve seguir, querendo garantir um planejamento centralizado. Deste educador, requer humildade das suas ações, melhor ainda, requer (re)avaliar as suas concepções, atitudes, a importância do seu papel (e da educação também), de preparar este sujeito para o mundo. Deste educador, espera-se que na promoção de interatividade seja capaz de favorecer um ambiente aberto para a criatividade coletiva e partilhada. 
Possibilitar a interatividade é promover que seja descentralizado o saber somente no professor, como bem destacou Silva (2000). E neste contexto, todos os envolvidos podem adotar a postura de aprendentes ativos, capazes de contribuir e cooperar uns com os outros, socializando as suas aptidões e desenvolvendo habilidades necessárias para enfrentar diferentes situações e buscar diferentes meios para as suas soluções.

Frente à postura deste educador, o mesmo estará motivando uma nova postura de atuação do aluno. Neste momento, destacamos a importância das responsabilidades, habilidades e competências que o aluno virtual deverá desenvolver, em prol da sua autoria de pensamento e autonomia das suas ações. É imprescindível que o aluno desenvolva as capacidades de comunicação, colaboração, criatividade e autonomia, disposto a enfrentar, buscar as 'soluções impostas'. Ele não mais poderá se colocar na posição passiva como muitos estão habituados, ou seja, ele deve se responsabilizar pelas suas próprias aprendizagens, na possibilidade de construir e reconstruir conhecimentos.

Complementando estas reflexões, Silva (2003a) destaca 3 (três) aspectos essenciais para desenvolver de fato a interatividade em espaços online:

- Participação colaborativa: participar não é apenas responder "sim" ou "não", prestar contas ou escolher uma opção dada, significa intervenção na mensagem como co-criação da emissão e da recepção

- Bidirecionalidade e dialógica: a comunicação é produção conjunta da emissão e da recepção, os dois pólos codificam e decodificam

- Conexões em teias abertas: a comunicação supõe múltiplas redes articulatórias de conexões e liberdade de trocas, associações e significações (p. 56).

Nos espaços interativos, a informação poderá ser questionada, defrontada, não se caracterizando como uma informação fechada, ou seja, a informação será compartilhada e ao mesmo tempo aberta para novas intervenções, favorecendo assim a criação coletiva. Não será somente mais um texto para ler ou assistir a um vídeo e a posição dada pelos autores será absoluta e única. Abre-se espaço para o diálogo e para a constante intervenção do leitor quanto aos meios utilizados, possibilitando e (re)significando assim os conceitos de autoria das ações dos sujeito envolvidos. O aprendente irá operar sob diferentes possibilidades na promoção de espaços interativos.

\subsection{Comunidades Virtuais de Aprendizagem}

O avanço das Tecnologias Digitais (TD), bem como a configuração de novas posturas a serem adotadas pelos sujeitos neste ciberespaço, tem favorecido a constituição de comunidades virtuais de aprendizagem (CVA) em meios educacionais. As comunidades como um todo, se constituem a partir de interesses, projetos, valores e necessidades similares entre seus integrantes, levando em conta as características sociais e educacionais que norteiam a criação deste grupo.

[...] as comunidades educacionais podem ser mais estimulantes e interessantes para quem trabalha com educação, porque elas unem pessoas que possuem interesses e destinos similares, ou seja, pessoas que não estão conectadas por acaso, como se verifica em outras áreas no ciberespaço (PALLOFF; PRATT, 2002, p. 47).

Mas, para viver e conviver em uma comunidade, limites e regras devem ser instaurados neste grupo, para que haja respeito mútuo nas trocas realizadas, de forma a considerar também as singularidades de cada membro. Geralmente estas regras são organizadas pelo moderador da comunidade e, conforme a condução das interações, podem ser debatidas e (re)ajustadas pelo grande grupo . $^{5}$

\footnotetext{
${ }^{5}$ Exemplo de regras utilizadas por comunidades virtuais:
} 
Para o sucesso dessa comunidade, a responsabilidade das ações e participação dos integrantes deverá ser mútua. Se houver uma participação desigual, o grupo poderá não ter suas ações efetivas. A ação negativa de um membro do grupo interfere no resultado dos objetivos a serem atingidos por estes como um todo.

Uma CVA implica a interação entre pares e a troca de papéis em diferentes momentos, consoante as necessidades. Para Morgado (2001), a aprendizagem colaborativa produz potencialmente maiores ganhos do que a aprendizagem individual, e não significa 'aprender em grupo', mas a possibilidade de o indivíduo beneficiar do apoio e da retroação de outros indivíduos durante o seu percurso de aprendizagem.

Portanto, o grupo é um espaço importante onde o sujeito pode, através de multi-interações, beneficiar-se de maneira a ter um aprendizado mais significativo. Mas para que isso ocorra, é necessário aprender a trabalhar e a se colocar em grupo e especificamente a interagir em ambientes de aprendizagem colaborativo, dispondo-se a compartilhar os conhecimentos e referências de informações que possui; a respeitar as opiniões dos colegas; a participar de discussões; a auxiliar colegas em suas dúvidas, etc. Para que o aluno possa adquirir essas competências, os cursos virtuais devem inicialmente orientá-los para gradativamente ser capaz de realizar essa atividade cada vez mais de forma autônoma.

Em cursos virtuais, o educador terá a função inicial de coordenador desta comunidade. A necessidade da 'presença' deste em cursos virtuais passa por um grupo de etapas que perpassa desde a maior necessidade de interferência até que este passe apenas para o papel de orientador. Morgado (2001) identifica estas cinco etapas:

- acesso e motivação: o aluno precisa conhecer o ambiente, os colegas, o processo, enfim de forma geral tudo é novidade para ele e o educador ainda será muito solicitado;

- socialização: o grupo precisa se conhecer e aprender a interagir e a se respeitar. $\mathrm{O}$ educador assume a postura mediadora, promovendo esta socialização, identificando indivíduos isolados e atraindo-os para as interações do grupo;

- partilha de informações: os alunos trocam informações, referências, idéias, opiniões, etc. e o educador precisa criar espaços que possibilitem ao grupo realizar esse compartilhamento;

- construção do conhecimento: o grupo começa a construir conclusões, fazendo relações com seu conhecimento prévio. Neste contexto o educador precisa oferecer feedbacks, verificando a coerência das conclusões, gerindo conflitos entre opiniões controversas, etc.;

- desenvolvimento: quando o grupo já possui autonomia para buscar conhecimento, interagir, colaborar, etc. de forma autônoma, o educador neste fase assume o papel de orientador do processo e as suas interações serão em menor quantidade e serão mais reativas às solicitações dos alunos.

Dessa forma, a negociação online deve ser estabelecida quando ocorrer conflitos em uma CVA. Um medidor se faz necessário neste momento, o qual estará retomando a organização e o foco da constituição deste grupo. Ele terá uma função muito importante para que haja sintonia nas trocas de mensagens entre este grupo, levando em conta o respeito ao ritmo e ao tempo de aprendizagem de cada membro. Ao mesmo tempo em que este mediador possui um determinado 'poder', ele também deverá possibilitar que outros membros também se coloquem nesta posição de

- Clube do Hardware, disponível em: http://forum.clubedohardware.com.br/regras-forumatualizadas/618586. Acesso em jul. de 2009.

V. $8 \mathrm{~N}^{\circ}$ 1, EAD, 2010 
mediador. Estas são situações significativas de aprendizagem para o grupo. Importante não deixar ao acaso determinadas situações, pois repercute no comportamento do grupo e pode deixar um clima tenso e de desconforto na condução das atividades.

\subsection{Ferramenta de Comunicação Assíncrona: o fórum de discussão}

O fórum de discussão é um espaço característico de portais, sites de relacionamentos e cursos online, usado para colocar temas em debate por um determinado grupo e a interação neste espaço ocorre principalmente pela linguagem escrita. Assim como requer a organização do grupo, requer planejamento para a condução das interações a serem realizadas neste espaço.

Em fóruns de discussão, todos os participantes possuem acesso as mensagens trocadas pelo grande grupo. Dessa forma, os interlocutores podem assumir posturas ativas no processo de interação.

As trocas de mensagem podem ser melhor elaboradas pelo autor, pois o discurso não será imediato como ocorre com a utilização da ferramenta de comunicação síncrona $^{6}$ (chat ou bate-papo). A linguagem escrita poderá ser mais estruturada e argumentada, devido a possibilidade do autor poder escrever, ler, reler, fundamentar suas idéias e concepções sobre o tema, antes de submeter a mensagem para o grande grupo. Dessa forma, cada integrante do seu grupo, na sua diferença, pode participar ativamente do debate, desenvolvendo assim suas competências de comunicação e contribuindo para o conhecimento coletivo.

A organização/gerenciamento e a clareza na condução de um fórum também se fazem necessário. Conforme Gonzáles (2006, apud DOMINGUES, 2006), devem ser definidos algumas normas iniciais pelo grupo, de forma a melhor conduzir a discussão. Este autor cita três itens a serem considerados: (a) o número de alunos que irão utilizar este fórum; (b) o tamanho da mensagem a ser submetida; e (c) definir o número de postagens permitidas por cada integrante do grupo.

Palloff e Pratt (2002) indicam uma média de 25 alunos por sala de aula virtual. Esta média de alunos influencia na proximidade das relações cognitivas e afetivas estabelecidas pelo grupo, bem como a constituição de regras para a utilização da ferramenta da comunicação.

Quanto ao tamanho da mensagem submetida pelo autor, esta também influencia na leitura, considerando que mensagens muito longas podem fazer com que o leitor perca o foco da leitura e a mesma pode ser tornar um discurso cansativo.

Quanto ao último item citado por Gonzáles (2006, apud DOMINGUES, 2006), a definição de um número de postagens por fórum de discussão, considera-se que não deve ser rígida, a fim de não impulsionar a obrigatoriedade ou até mesmo limitar a participação, prejudicando a interação entre o grupo. Um item que pode ser interessante acrescentar, refere-se a postagem de argumentos que não induzisse a idéia de repetição de outras mensagens já submetidas, mas que pudesse elencar a sua posição realizando links com os outros posicionamentos, assim conectando os argumentos já citados no fórum.

Frente a estas considerações, a postura do educador na mediação em fóruns de discussão deverá ser a de: estimular e orientar a discussão, mantendo, contudo, um certo distanciamento, para não intervir excessivamente nos processos individuais e coletivos de aprendizagem. Também, ter como foco a inclusão de todos e a valorização de cada

\footnotetext{
${ }^{6}$ A comunicação ocorre em tempo real. A mensagem emitida por uma pessoa é recebida e respondida instantaneamente por outras. Ex.: telefone, messenger, chat, participação em áudio e videoconferências. Fonte: http://paginas.terra.com.br/educacao/eadcamp/glossario.htm\#A. Acesso em jul. de 2009.
} 
participação, e dar oportunidade para o surgimento e convivência de opiniões díspares. Além disso, para a mediação dos fóruns, o educador deve possuir um amplo domínio do material do curso, procurar fontes alternativas de informação para que suas informações possam enriquecer o debate.

Outro ponto em destaque, refere-se ao tempo de duração da discussão. Durante a discussão em um fórum, não será obrigatório estar fixo a um único ponto durante o debate, mas abrir espaços para ir além do tema proposto inicialmente, para que cada membro do grupo firme seu posicionamento, não somente apoiando-se em conceitos empíricos e de senso comum, mas buscando o apoio em outros autores. Dessa forma, deve-se estimular e permitir que todos os membros dessa CVA sejam protagonizadores de suas ações. Não será somente um espaço para responder a questionamentos ou considerar a sua participação como mais uma atividade a ser cumprida, mas um espaço para reflexão.

[...] podemos caracterizar então o fórum virtual de discussões em EAD via web como uma modalidade de conversação assíncrona, intencional, dirigida a uma finalidade pedagógica de construção/reconstrução de saberes, composta por segmentos interlocutivos que constituem, a um só tempo, objetos de leitura e indicadores da pessoalidade de seu locutor [...] (OLIVEIRA; FILHO, 2006, p. $02)$.

Estes autores indicam dois estilos de comunicação unidirecional presentes em algumas CVAs. No primeiro estilo, observa-se na utilização do fórum, tanto na introdução e no seu fechamento do mesmo, a inclusão de mensagens do educador direcionada para o aluno. Este estilo de comunicação pode levar ao enfraquecimento das interações e tornando cansativa a relação estabelecida, pois o aluno acaba esperando o posicionamento do educador e pouco se preocupa em interagir frente ao posicionamento dos colegas. No segundo estilo, o educador lança a pergunta e espera-se uma resposta pré-definida dos alunos. Este estilo pode até indicar um cenário de 'bons debatedores', mas acaba por reproduzir o modelo de comunicação tradicional. Também pode haver outra tentativa, do educador silenciar-se frente ao uso do fórum, acreditando que poderá emergir a participação destes sem a sua intervenção. Esta atitude pode ser vista como meio de incentivar a autonomia dos alunos, mas ao mesmo tempo, pode parecer para estes uma forma de abandono.

Outro ponto em destaque refere-se à avaliação de participação e interação através dessa ferramenta. Muitos alunos questionam a necessidade de avaliação realizada a partir da interação nos fóruns de discussão. Oliveira e Filho (2006) apresentam em seu artigo os critérios utilizados na realização de um curso, conforme segue.

\begin{tabular}{|l|l|}
\hline Pontos & Tipo de participação \\
\hline 0 & Passiva (só recebe as mensagens e não posta coisa alguma). \\
\hline 1 & Participações que não contribuem para a discussão em pauta. \\
\hline 2 & Contribuição pontual isolada (cita definições, aponta uma URL) \\
\hline 3 & $\begin{array}{l}\text { Contribuição questionadora (propõe dilemas, apresenta alternativas e pede } \\
\text { posicionamentos). }\end{array}$ \\
\hline 4 & $\begin{array}{l}\text { Contribuição debatedora (comenta contribuições anteriores com propriedade), responde a } \\
\text { questionamento ou apresenta contra-argumento (pró e contra). }\end{array}$ \\
\hline 5 & $\begin{array}{l}\text { Contribuição sintetizadora (coleta segmentos da discussão, ajusta, adapta, elabora parecer } \\
\text { conclusivo). }\end{array}$ \\
\hline
\end{tabular}

Tabela 1 - Critérios de avaliação do fórum utilizado pelo Laboratório de Telecomunicação da UFRGS Fonte: OLIVEIRA; FILHO, 2006, p. 09

Esta pode ser um modelo em como avaliar a discussão de um fórum, na qual elenca as competências e conceitos a serem despertados na discussão com os alunos. 
Além disto, pode auxiliar na organização do educador na condução da discussão realizada.

Realizando uma análise dos fóruns de discussão, o educador poderá verificar as mensagens dos alunos coletiva e individualmente, podendo observar toda a trajetória do aluno durante o curso, perceber seus momentos de inquietação e as posturas adotadas (debatedor, questionador...), ou até observar momentos de mais passividade frente a um determinado tema. No coletivo, o educador pode perceber se há algum momento de desconforto no grupo e traçar novas estratégias para que as interações ocorram de forma mais saudável, levando em consideração as diferenças existentes no grupo. Os critérios de avaliação, necessariamente, não precisam ser rígidos, mas oferecem suporte ao educador no seu feedback quanto a participação do grupo durante a realização de cursos virtuais.

Dessa forma, o educador não será apenas 'alguém' de forma operacional que abre um fórum inserindo um questionamento e o fecha simplesmente após o período determinado. Será 'alguém' que interage com as idéias e argumentos postos pelos alunos, 'alguém' que os desafia e utiliza o fórum como um mediador das relações de ensino e de aprendizagem nas interações estabelecidas. Interessante é sempre dialogar com o grupo e verificar/pesquisar novas possibilidades de uso dessa ferramenta de comunicação.

Por fim, o fórum deve ser muito mais que um repositório de informações, deve assumir o papel de mediador entre os argumentos e posicionamentos entre os componentes da CVA.

\section{Proposta de curso de extensão}

Neste projeto, o curso possui duração de $40 \mathrm{~h}$, com a orientação de estudo para 5 h semanais, totalizado em um período de 2 meses. Cada turma será composta de no máximo 30 alunos.

O curso está dividido em 4 unidades, seguindo os seguintes temas:

- Unidade 1: Mediação e Abordagens Pedagógicas - 10h

- Unidade 2: Comunidades Virtuais de Aprendizagem - 10h

- Unidade 3: Interatividade e Fóruns/Lista de discussão - 10h

- Unidade 4: Estratégias e Avaliação - 10h 


\begin{tabular}{|c|c|c|c|c|c|}
\hline \multicolumn{3}{|c|}{ CINTED-UFRGS } & \multicolumn{3}{|c|}{ Novas Tecnologias na Educação } \\
\hline Unidade & Conteúdtos & Objetivos & $\begin{array}{c}\text { Recursos e } \\
\text { ferramentas }\end{array}$ & Interatividade & Đeseriȩão da Đinâmica/Atividade \\
\hline $\begin{array}{l}\text { Mediação e } \\
\text { Abordagens } \\
\text { Pedagógicas }\end{array}$ & $\begin{array}{l}\text { O conceito e o papel da } \\
\text { mediação. } \\
\text { A mediação em espaços } \\
\text { presenciais e virtuais. } \\
\text { Abordagens pedagógicas } \\
\text { online. }\end{array}$ & $\begin{array}{l}\text { Promover um espaço para } \\
\text { interação, buscando } \\
\text { entender e conhecer as } \\
\text { diferentes abordagens } \\
\text { pedagógicas online, } \\
\text { avaliando os aspectos com } \\
\text { relação à mediação } \\
\text { pedagógica em fóruns de } \\
\text { discussão em cursos } \\
\text { virtuais. }\end{array}$ & $\begin{array}{c}\text { Material de apoio, } \\
\text { Diário e Fórum de } \\
\text { discussão geral e } \\
\text { P\&R. }\end{array}$ & $\begin{array}{l}\text { Individual e com o } \\
\text { grande grupo de } \\
\text { alunos. }\end{array}$ & $\begin{array}{l}\text { Semana 1: Leitura do material de } \\
\text { apoio, participação no fórum de } \\
\text { apresentação e escrita no diário } \\
\text { sobre sua experiência em fóruns de } \\
\text { discussão. O prazo de realização da } \\
\text { atividade será de uma semana. } \\
\text { Semana 2: fórum de P\&R sobre } \\
\text { abordagens pedagógicas online. }\end{array}$ \\
\hline $\begin{array}{l}\text { Comunidades } \\
\text { Virtuais de } \\
\text { Aprendizagem }\end{array}$ & $\begin{array}{l}\text { Conceitos e constituição de } \\
\text { uma CVA. } \\
\text { Comunicação e Linguagem } \\
\text { virtual. }\end{array}$ & $\begin{array}{l}\text { Promover um espaço de } \\
\text { reflexão quanto às relações } \\
\text { e regras grupais em meios } \\
\text { virtuais. } \\
\text { Estabelecimento de regras } \\
\text { de comunicação. } \\
\text { Usar a linguagem virtual } \\
\text { para tornar um ambiente } \\
\text { mais afetivo, preservando } \\
\text { as características de um } \\
\text { espaço educativo. }\end{array}$ & $\begin{array}{l}\text { Wiki e Fórum (geral } \\
\text { e grupos visíveis). }\end{array}$ & $\begin{array}{l}\text { Grande grupo de } \\
\text { alunos e em pequenos } \\
\text { grupos. }\end{array}$ & $\begin{array}{l}\text { Semana 1: Leitura do material de } \\
\text { apoio e discussão no fórum através } \\
\text { da Wiki o grupo irá debater } \\
\text { (considerando a experiência docente } \\
\text { e discente) e elencar as regras do } \\
\text { grupo para se comunicar nos fóruns } \\
\text { do curso e diferentes fóruns já } \\
\text { apresentados pelo curso, como por } \\
\text { exemplo Fórum Social. } \\
\text { Semana 2: Leitura do material de } \\
\text { apoio. Qual o papel da linguagem } \\
\text { neste espaço. O grupo será dividido } \\
\text { em grupos de } 4 \text { componentes. A } \\
\text { equipe do curso irá elencar os } \\
\text { componentes. Cada grupo irá } \\
\text { receber algum recurso/meio } \\
\text { (imagem, vídeo, música...) que } \\
\text { inicie a discussão entre eles sobre o } \\
\text { tema Comunicação e Linguagem } \\
\text { Online, que irá norteá-la a partir do } \\
\text { texto base da semana. Os grupos } \\
\text { terão acesso a todas as discussões } \\
\text { realizadas, podendo identificar as } \\
\text { posturas e interpretações dadas. } \\
\text { Eles poderão comentá-las entre si } \\
\text { sobre a dinâmica dos outros grupos. }\end{array}$ \\
\hline $\begin{array}{l}\text { Interatividade e } \\
\text { Fóruns/Lista de } \\
\text { discussão }\end{array}$ & $\begin{array}{c}\text { Ferramentas de } \\
\text { comunicação assíncrona. } \\
\text { Interação e Interatividade } \\
\text { em EAD. }\end{array}$ & $\begin{array}{l}\text { Caracterizar positiva e } \\
\text { negativamente o uso do } \\
\text { fórum de discussão em } \\
\text { cursos virtuais. } \\
\text { Identificar os tipos de } \\
\text { fóruns disponíveis no AVA } \\
\text { MOODLE. } \\
\text { Refletir sobre as diferenças } \\
\text { entre interação e } \\
\text { interatividade em espaços } \\
\text { virtuais. }\end{array}$ & $\begin{array}{l}\text { Escolha e Fórum } \\
\text { (discussão simples e } \\
\text { fórum em grupos } \\
\text { separados). }\end{array}$ & $\begin{array}{l}\text { Grande grupo de } \\
\text { alunos e em pequenos } \\
\text { grupos. }\end{array}$ & $\begin{array}{l}\text { Semana 1: Técnica "telefone sem } \\
\text { fio". Discussão simples sobre o } \\
\text { tema interatividade em EAD. Os } \\
\text { alunos deverão responder a escolha } \\
\text { forme o seu grupo para } \\
\text { desenvolverem a atividade da } \\
\text { próxima semana. } \\
\text { Semana 2: em duplas, elaborar uma } \\
\text { estratégia de utilização de um fórum } \\
\text { de discussão. Cada dupla irá } \\
\text { determinar o tema, objetivos } \\
\text { cronograma e avaliação da } \\
\text { atividade. A atividade será aplicada } \\
\text { em outro grupo na próxima semana } \\
\text { de atividades. }\end{array}$ \\
\hline $\begin{array}{l}\text { Estratégias e } \\
\text { Avaliação }\end{array}$ & $\begin{array}{l}\text { Tipos de Fóruns e suas } \\
\text { características. } \\
\text { Estratégias pedagógicas e } \\
\text { fórum de discussão. } \\
\text { Tipos de avaliação em } \\
\text { EAD. }\end{array}$ & $\begin{array}{c}\text { Refletir quanto a avaliação } \\
\text { da participação em fóruns } \\
\text { de discussão, suas } \\
\text { estratégias e os tipos de } \\
\text { avaliação. }\end{array}$ & $\begin{array}{l}\text { Diário e Fórum } \\
\text { (grupos separados e } \\
\text { discussão geral). }\end{array}$ & $\begin{array}{l}\text { Individual, com o } \\
\text { grande grupo de } \\
\text { alunos e em pequenos } \\
\text { grupos. }\end{array}$ & $\begin{array}{c}\text { Semana 1: aplicar a estratégia } \\
\text { elaborada na semana anterior com } \\
\text { outra dupla, assumindo posições } \\
\text { diferentes. } \\
\text { Semana 2: discutindo sobre a } \\
\text { avaliação de fóruns de discussão } \\
\text { (diferenças entre participação e } \\
\text { interatividade). Exposição das } \\
\text { experiências ocorridas nos trabalhos } \\
\text { em grupo. Entrega do trabalho final } \\
\text { através do diário, identificando a } \\
\text { avaliação. }\end{array}$ \\
\hline
\end{tabular}

Tabela 2 - Matriz de Design Pedagógico do Curso

\section{Considerações Finais}

Este movimento, na elaboração deste projeto, foi incitado na necessidade de compreender as posturas de comunicação e atuação nos espaços virtuais de ensino e de aprendizagem e os movimentos de interação do grupo para promover uma prática emergente. Assim, a mediação torna-se um instrumento de aprendizagem significativa, ou seja, estará presente não só na postura adotada pelos educadores, mas pelas suas estratégias de ensino, em como estabelece a sua relação com o grupo, com o conteúdo e 
com projetos (pesquisa), estratégias estas que possibilitam ao aluno se colocar na posição de aprendente ativo.

Buscou-se nesta proposta de curso, o estudo em que se proporcione um ambiente que valorize a experiência, a troca, a criatividade, a convivência e o respeito. Ao propiciar um ambiente de aprendizagem colaborativa, faz com que o movimento de interação desperte, provoque e desafie o interesse, a busca - e a necessidade - por diferentes experiências e a motivação para persistir neste processo de aprendizagem contínuo.

Dessa forma, a EAD está apoiada pelo viés da comunicação, principalmente pela qualidade dessa mediação através do uso das tecnologias.

\section{Referências Bibliográficas}

BELLONI, Maria Luiza. Educação a distância. Campinas: Autores Associados, 2001.

DOMINGUES, Elidiani. Avaliação de fóruns de discussão. Collaborate with Twiki. 2006. Disponível em:

http://wiki.sintectus.com/bin/view/EaD/AvaliacaoDeForunsDeDiscussao. Acesso em: 20. de jul. de 2009.

LÉVY, Pierre. As mutações da educação e a economia do Saber. In:

Cibercultura. São Paulo: Ed. 34, 1999, p.169-176.

O que é virtual? São Paulo: Ed. 34, 6ª reimpressão, 2003.

MORGADO, Lina. O papel do professor em contextos de ensino on-line: problemas e virtualidades. In: Discursos. Série, 3. Universidade Aberta, 2001. p. 125-138.

Disponível em: http://www.univ-ab.pt/ lmorgado/Documentos/tutoria.pdf. Acesso em: 01 de jul. de 2009.

OLIVEIRA, Sheila da Costa; FILHO, Gentil José de Lucena. Animação de fóruns virtuais de discussão: novo caminho para a aprendizagem em EAD via web. In: Novas tecnologias na Educação. v. 4. n. 2. CINTED-UFRGS. Dezembro, 2006. Disponível em: http://www.cinted.ufrgs.br/renote/dez2006/artigosrenote/25159.pdf. Acesso em: 20 de jul. de 2009.

PALLOFF, Rena M.; PRATT, Keith. Construindo comunidades de aprendizagem no ciberespaço: estratégias eficientes para a sala de aula on-line. Porto Alegre: Artmed, 2002.

RAMAL, Andréia Cecília. Educação na Cibercultura: hipertextualidade, leitura, escrita e aprendizagem. Porto Alegre: Artmed, 2002.

SILVA, Marco. Sala de aula interativa. Rio de Janeiro: Quartet, 2000.

Criar e professor um curso online: relato de experiência. IN: SILVA,

Marco (Org.). Educação online: teorias, práticas, legislação e formação corporativa. São Paulo: Loyola, 2003a, p. 51-73. 
. Sala de aula interativa: a educação presencial e a distância em sintonia com a era digital e dom a cidadania. 2003b. Disponível em:

http://www.senac.br/informativo/BTS/272/boltec272e.htm Acesso em: 05 de jul. de 2009. 